\title{
Editor's message: building capacity and partnerships towards sustainable utilization of groundwater in Africa
}

\author{
Yongxin Xu
}

This Editor's Message advises the international groundwater fraternity of new opportunities in hydrogeological developments in Africa. It is a fact that groundwater plays a vital role in socio-economic and ecological services in the continent but it has been largely neglected in the past. With the 6th Ordinary Session of AMCOW (African Ministers' Council on Water) held in Brazzaville, Congo in late May 2007, the profile of groundwater in the continent has been raised.

\section{Current situation}

Taking a continent-wide view of the groundwater issues of Africa, the following picture clearly emerged at the Session in May 2007:

\section{- On the ground:}

There is widespread degradation of groundwater resources, leading to a diminishing resource base, mainly as a result of pollution of underlying groundwaters in both urban and rural areas, but also over-abstraction, particularly in relatively higher-yielding aquifers and aquifer systems. On the other hand, there is an issue of resource wastage where groundwater is sleeping and still to be explored and tapped for human benefits. At scales of transboundary aquifer systems, there are strong indications of potential human conflicts, not due to physical cross-boundary flow as such, but due to its unseen and poorly understood nature, and especially unwillingness to cooperate on resource sharing. Again, these problems are exacerbated through the well-known human challenges of equity, justice, power and governance. These are at the heart of the debate on any natural resource and particularly pressing for groundwater because of its hidden

Received: 27 November 2007 / Accepted: 29 January 2008

Published online: 12 March 2008

(C) Springer-Verlag 2008

\section{Y. Xu (}

UNESCO Chair in Hydrogeology,

University of the Western Cape,

Modderdam Road, Bellville, Cape Town 7535, South Africa

e-mail: yxu@uwc.ac.za nature. The challenge is a major one in Africa, because of the much greater lack of information and knowledge about the resources and also a general lack of appropriate governance structures in place to help achieve objectives of equity and sustainability.

- At management level:

Given Africa's largely hard-rock environment, groundwater resources are exploited through many widely distributed and relatively small individual sources and there is a lack of appropriate planning, financing, developing and sustainable utilization of groundwater resources. Appropriate financing mechanisms need to be realistically established to cater for relatively distributed users.

- On the underlying cause of resource degradation:

Fundamentally, it is recognized that there is a lack of data, information and knowledge about groundwater and its functioning as an important component in the overall hydrological and environmental system. There is a serious lack of institutional capacity in this regard. This problem is an underlying cause for most of the other issues. The problems are so acute and serious that African hydrogeologists have to seek political intervention through the AMCOW to rectify and/or turn around the above-mentioned situation, and to realize the Africa Water Vision where "Groundwater resources are valued and utilized sustainably by empowered stakeholders" (AMCOW 2005).

\section{AMCOW recommendations and follow-up}

The Brazzaville meeting was very successful from a hydrogeologist's point of view. A strong contingent of African hydrogeologists, who were sponsored by UNEP (UN Environment Programme) and UNESCO, actively participated in the meeting. Thanks to the organizer's efforts, the intended side event on groundwater management changed to a 30-minute plenary session with all the AMCOW Ministers present, representing nearly 40 African states and many international organizations. Ethiopia's Minister and Namibia's Deputy Minister cochaired the event, and some 200 copies of the brochure entitled 'Partnerships Towards Sustainable Utilization of Groundwater in Africa' (AMCOW 2007) were distributed to participants. Centered on the Africa Groundwater Initiative jointly presented by Eberhard Braune and 
Yongxin $\mathrm{Xu}$, the discussion was very constructive and fruitful. For instance, a delegate from North Africa requested that they formally take up their role in the Initiative which, up until then, involved mostly SubSaharan Africa. Tanzania's Minister felt that groundwater resource mapping should be part of any management initiative and this was strongly endorsed by others.

With respect to the Africa Groundwater Initiative, the 6th Session of AMCOW decided to request its Technical Advisory Committee (TAC) to:

- Promote the institutionalization of groundwater management by river basin organizations to ensure regional ownership of the initiative

- Create synergy with the Rural Water Supply and Sanitation Initiative (RWSSI) to ensure groundwater's inclusion in resource assessment and the sustainable management of groundwater resources

- Become the custodian through which the strategic initiative can be fast-tracked and a continent-wide impact can be ensured

- Consider endorsing and supporting efforts to secure core financial support from the African Water Facility, which could be leveraged to raise additional resources from development cooperation partners such as the European Union

Because this is a long-term challenge requiring a lot of buy-in and commitment, a Ministerial Groundwater Consultative Forum in the form of an informal workshop was held in Stockholm during the World Water Week conference (August 2007) to investigate the modality of how to implement the recommendations. Formulating a Groundwater Commission for Africa was consequently conceptualized during the workshop. A formal meeting regarding the establishment of the Groundwater Commission took place in Nairobi, Kenya in November 2007. This will definitely raise the priority for groundwater in Africa in the longer term.

\section{A new opportunity}

In November 2005, concerned scientists and major stakeholders from the African continent met on the issue of groundwater protection in Africa at the UNESCO Chair based at the University of the Western Cape (UWC), South Africa in an intensive workshop. Representatives from AMCOW, UNEP, including the Global Environment Monitoring System Programme (GEMS/Water), UNESCO, UN Economic Commission for Africa (UNECA), UN Water/ Africa, the International Atomic Energy Agency (IAEA), the World Bank, the African hydrogeological community, the International Association of Hydrogeologists (IAH), local government and northern and southern hemisphere science representatives reached consensus on the importance of the issue and the need for national, regional, and international actions. This message was jointly conveyed by UNEP, UNESCO and the UWC during the session of Groundwater
Resources Management and Protection in Africa of the 4th World Water Forum held in Mexico, March 2006. The Mexico session was well attended by nearly 200 delegates from all over the world. The issues were further discussed at the AMCOW Conference of African River and Lake Basin Organizations in Kampala, Uganda in October 2006; and in particular, there was focus on managing and protecting groundwater resources within the framework of RBOs (River Basin Organizations) in implementing the Africa Water Vision 2025. This resulted in the formal presentation of the Initiative in Brazzaville.

Given the need to start somewhere and also to create momentum for the regional process, the Southern African Development Community (SADC) representatives approached the UNESCO Chair on Groundwater immediately after the Brazzaville meeting, to ask whether it could do a scoping study of groundwater management in SADC member countries. The call was met with a very positive response from the South Africa Water Research Commission. The first funds that were approved have already been used to develop and test a protocol for this purpose in South Africa. The protocol will rely on whatever SADC information can be obtained relatively easily. To bring in SADC more fully, it is hoped that the donors in the region will fund a follow-up project with a workshop that will include a core relevant to all countries. The results will be reported to the SADC Ministers of Water in due course; and already the UNEP and UNESCO have indicated willingness to bring representatives from the other African sub-regions to the above workshop to build bridges with respect to activities in the rest of Africa.

With the political buy-in from Brazzaville to Nairobi, hydrogeologists in Africa are obviously excited, but recognize that this is only the very beginning. With an AMCOW umbrella, there should now be continuity and a fresh start, and hopefully also coordination of effort. In the author's view, the first step after the scoping exercise should be sound representative assessment of groundwater's role in socioeconomic development in the SADC region and Africa as a whole. We, the hydrogeologists in Africa, are calling on the international community to join us in building capacity and good partnerships towards sustainable utilization of groundwater in Africa in whatever way you can.

Acknowledgements The long-standing promotion and support by Salif Diop (UNEP - Division of Early Warning and Assessment (DEWA)), Emmanuel Naah (UNESCO's Nairobi Office) and Eberhard Braune (UWC) for groundwater in Africa is greatly acknowledged.

\section{References}

AMCOW (2005) Message to decision-makers: outcomes of the International Workshop on Groundwater Protection in Africa, 28-30 November 2005, Cape Town. http://www.amcow.org/ uploads/9DecisionMakers.doc

AMCOW (2007) Partnerships towards sustainable utilization of groundwater in Africa. Brochure prepared jointly by the UNESCO International Hydrological Programme, UNEP and the University of the Western Cape as input to the 6th Session of AMCOW, held in Brazzaville 